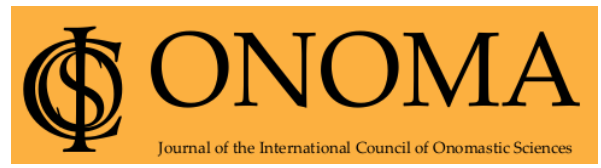

Onoma 56

Journal of the International Council of Onomastic Sciences

ISSN: 0078-463X; e-ISSN: 1783-1644

Journal homepage: https://onomajournal.org/

\title{
Middle English names of workers in metal: Etymology and functioning as common nouns and proper names
}

\section{Oksana Dobrovolska*}

Department of English Philology, Faculty of Foreign Languages, Vasyl Stus Donetsk National University, Vinnytsia, Ukraine

To cite this article: Dobrovolska, Oksana. 2021. Middle English names of workers in metal: Etymology and functioning as common nouns and proper names. Onoma 56, 123-148. DOI: 10.34158/ONOMA.56/2021/7

To link to this article: https://doi.org/10.34158/ONOMA.56/2021/7

(C) Onoma and the author.

\section{Article history}

Received on 22 March 2021.

Final form accepted on 10 December 2021.

Published online on 13 December 2021.

Middle English names of workers in metal: Etymology and functioning as common nouns and proper names

Abstract: The article is devoted to the study of etymological composition and functional differentiation of the semantic group of the names of workers in metal. The vocabulary is distributed into three parts with regards to its origin, or the origin of word-stems: native words, loan-blends, and loan-words. The vocabulary is differentiated into three groups according to the functional principle: occupational terms as common nouns and proper names with both the functions of identification (individualization) and classification (categorization); occupational terms as proper names with the only function of identification, and occupational terms as common

* Contact: Department of English Philology, Faculty of Foreign Languages, Vasyl Stus Donetsk National University, 21, 600-richya str., Vinnytsia, 21021, Ukraine, oxanadobrovolska@ukr.net 
nouns with the only function of classification. The prevalence of the vocabulary with the function of identification over that with the only function of classification in the ratio 9:1 proves the fact of active usage of the names of workers in metal as anthroponyms in the Middle English period.

Keywords: Common nouns, Middle English, occupational terms, proper names.

\section{Noms anglais moyens des métallurgistes : Étymologie et fonctionnement en tant que noms communs et noms propres}

Résumé : L'article est consacré à l'étude de la composition étymologique et de la différenciation fonctionnelle du groupe sémantique des noms des ouvriers du métal. Le vocabulaire est réparti en trois parties en ce qui concerne son origine ou l'origine des tiges de mots : mots natifs, mélanges de prêts et mots de prêts. Le vocabulaire est différencié en trois groupes selon le principe fonctionnel : termes professionnels comme noms communs et noms propres ayant à la fois les fonctions d'identification (individualisation) et de classification (catégorisation) ; termes professionnels comme noms propres ayant pour seule fonction d'identification, et termes professionnels comme noms communs ayant pour seule fonction de classification. La prédominance du vocabulaire à fonction d'identification par rapport à celui à seule fonction de classification dans le rapport $9: 1$ prouve l'usage très actif des noms des ouvriers du métal comme anthroponymes à l'époque du moyen anglais.

Mots-clés : Noms communs, anglais moyen, termes professionnels, noms propres.

\section{Mittelenglische Namen von Metallarbeitern: Etymologie und Funktion als gebräuchliche Namen und Eigennamen}

Zusammenfassung: Dieser Artikel widmet sich der Untersuchung der etymologischen Zusammensetzung und funktionalen Differenzierung der semantischen Gruppe der Namen von Arbeitern in Metall. Das Vokabular ist hinsichtlich seiner Herkunft oder der Herkunft von Wortstämmen in drei Teile unterteilt: einheimische Wörter, Leihmischungen und Leihwörter. Das Vokabular wird nach dem Funktionsprinzip in drei Gruppen unterteilt: Berufsbegriffe als gebräuchliche Substantive und Eigennamen mit den Funktionen Identifikation (Individualisierung) und Klassifikation (Kategorisierung); Berufsbegriffe als Eigennamen mit der einzigen Funktion der Identifizierung und Berufsbegriffe als gebräuchliche Substantive mit der einzigen Funktion der Klassifizierung. Die Verbreitung des Wortschatzes mit der Funktion der Identifikation gegenüber der mit der einzigen Funktion der Klassifizierung im Verhältnis 9:1 beweist die sehr aktive Verwendung der Namen von Metallarbeitern als Anthroponyme in der mittelenglischen Zeit.

Schlüsselbegriffe: Gebräuchliche Substantive, Mittelenglisch, Berufsbegriffe, Eigennamen. 


\title{
Middle English names of workers in metal: Etymology and functioning as common nouns and proper names
}

\author{
OKSANA DOBROVOLSKA
}

\section{Introduction}

The issues of language development and its causation have long been the focus of different interpretations of linguists, particularly in the scholarly works of Wilhelm von Humboldt, Jacob Grimm, Friedrich Schlegel, August Schleicher, Heymann Steinthal, Hermann Paul, Berthold Delbrück, Hermann Osthoff, Karl Brugmann, Antoine Meillet, Charles Bally, Ismail Sreznevsky, Jan Baudouin de Courtenay, Alexander Potebnya et al. Methodological bases of the diachronical studies lie in the following principles: 1) historical attitude towards the language phenomenon and treatment of language as a historic category (i.e. the principle of historicism); 2) consideration of language structure and its functioning as the complex system of signs (i.e. the principle of consistency in the study of language phenomena); 3) consideration of dialectic language evolution as indissoluble unity with the community development under the influence of internal and external factors.

In modern linguistics, it is still topical to provide a comprehensive disclosure of the issues of language evolution and language interference, in particular functional assimilation of borrowings (i.e. their acquisition of native usage and speech activity) and aspects of systematization of vocabulary in parameters of the complex dynamic adaptive system and on the basis of manifold and numerous empirical material, viewed within the long chronological period, viz. the idea of creation of large surname databases to statistical study of their changes, development, and distribution (McClure \& Hanks \& Coates 2012; McClure 2013, 2014; Hanks \& Parkin 2016; Hanks \& Coates \& McClure 2016).

Such profound studies of language evolution may be based upon the semantic group of occupational terms, especially while being viewed in different aspects of their functioning within the periods of language development (viz. McClure 2011a, 2011b). One of the leading role of medieval occupational terms as the source of family names (medieval bynames and hereditary surnames) means that Middle English occupational terms fulfilled both the functions of classification and identification, as far as they were used as appellatives and anthroponyms; as regards the meaning of these bynames, 
occupational terms belong to the semantic category of social function (Reaney 1966, 1967; Brylla 2016).

Medieval occupational terms, in particular their structure and functioning, have been the focus of linguistic studies in cognitive and onomasiological aspects, as well as through the lens of their etymology and linguistic development (McClure 2010a, 2010b; Solonovich 1986; Shilova 2006; Dobrovolska 2016, 2017). Numerous linguistic papers, which contain terms of occupation and office, serve to be the lexicographic sources of English historical lexicology in general, and personal names study in particular (Ekwall 1947; Fransson 1935; Mills 1968; Otto 1938; Reaney 1966, 1967; Tengvik 1938; Thuresson 1950).

The following general issues are the focus of our research:

1) functional differentiation of Middle English occupational terms in accordance with two kinds of nominative function, on the basis of the idea that all the nominative units are divided into the common nouns, which fulfil the function of classification, or categorization, and the proper names, which fulfil the function of identification, or individualization (viz. the differentiation of categorial and proprial meaning) (Nyström 2016);

2) etymological distribution of Middle English occupational terms according to their origin or the origin of their word-stems;

3) semantic taxonymy of Middle English occupational terms according to their lexical meaning or the meaning of their word-stems.

The general object of our investigation is Middle English semantic system, in particular the lexical semantic group of occupational terms as its subsystem; the partial object of our investigation is the subgroup of the names of workers in metal as the subsystem of the names of artisans.

The general aim of our investigation is to reconstruct the development of the semantic group of Middle English occupational terms; the partial aim is to reconstruct the development of semantic subgroup of the Middle English names of artisans, in particular the names of workers in metal. We set forth the following particular tasks of the investigation described in this paper:

1) collect Middle English occupational terms on the basis of historical dictionaries;

2) distribute the occupational terms within the groups as to the kinds of nominative function they perform (either classification, or identification, or both);

3) fulfil the lexical semantic grouping of Middle English occupational terms within subgroups and sets of synonyms;

4) give the observed phenomena absolute and relative quantitative characteristics, and display the data of calculations in tables. 


\section{Research methods}

General procedure of our research comprises the following steps:

1) distribution of occupational terms within the languages according to the origin of word-stems (native words and borrowings, which were assimilated in the English language or served the motivational bases of loan-blends);

2) distribution of occupational terms according to the kind of nominative function, particularly that of classification (as in common nouns) or identification (as in proper names), within the following functional groups:

Group 1 - the occupational terms as common nouns and proper names, which fulfilled the functions of classification and identification;

Group 2 - the occupational terms as proper names only, which fulfilled the only function of identification; as far as our knowledge of their existence in Middle English is only based on the anthroponymic data, we consider them to be reconstructed;

Group 3 - the occupational terms as common nouns only, which fulfilled the only function of classification;

3 ) grouping of occupational terms within the sets of synonyms;

4) comparative characteristics of the observed phenomena in the absolute and relative quantitative numbers, as well as representation of these data in tables.

We used the following methods of investigation: general scientific inductive-deductive method as the main method for the reconstruction of the development of the semantic system, especially the techniques for the study of the lexicographic sources, theoretical analysis of the data obtained, the analysis of the vocabulary definitions; techniques for thematic and semantic classifications, etymological analysis, morphemic analysis, techniques for linguistic interpretation, quantitative analysis and the language attribution of its results; linguistic comparative historical method, especially the comparative lexicographic analysis of the data of historical dictionaries.

The following historical and etymological dictionaries are the sources of our investigation:

1) Simpson, John \& Weiner, Edmund (eds.). 1989. The Oxford English dictionary (OED), 2nd ed., 20 vols. Oxford, Great Britain: Oxford University Press.

2) Lewis, Robert E. et al. (eds.). 1952-2001. Middle English dictionary (MED). Ann Arbor: University of Michigan Press. Online edition: McSparran, Frances et al. (eds.). 2000-2018. Middle English compendium. Ann Arbor: University of Michigan Library.

3) Reaney, Percy Hide. 1966. A dictionary of British surnames (DBS). London, Great Britain: Routledge and Kegan Paul. 


\section{Results and discussion}

The total number of Middle English occupational terms is 2417 (including 2015 surnames, which are represented in their 7429 spelling variants in 10204 occurrences); $9 \%$ of them (209 words) are the names of workers in metal, which constitutes $21 \%$ of the total number (1004 words) of the Middle English names of artisans (viz. Dobrovolska 2018). We distribute them as to their origin or the origin of their word-stem into three groups: 1) native vocabulary, 2) loan-blends, and 3) lexical borrowings.

\subsection{Native vocabulary (106)}

Middle English native names of workers in metal are 106 in number and constitute $51 \%$ of their total number within the thematic group of Middle English names of workers in metal, and $11 \%$ of the total number of the Middle English names of artisans. We distribute them within the following functional and semantic subgroups.

\subsubsection{Middle English native occupational terms with both the functions of classification and identification (36):}

1) the names of smelters and founders: blouere; 2) the names of blacksmiths: brāsier, hamer smith, rough(e $\sim$ smith, shōer, smith, smith wif, smithiere, whitesmith; 3) the names of turners and polishers: grindere, shere grindere, throuer; 4) the names of locksmiths: lokier(e, lok smith; 5) the names of craftsmen which make household utensils: hard-wāreman, potter (e, siver, tinker (e, tinkler; 6) the names of craftsmen who make needles, wires, studs, spurs and nails: nailer (e, nẹdlere, spōrier, wīr drawere; 7) the names of armorers: blăd(e) smith, shẹld makere, shēther(e, strenger, streng makere; 8) the names of masters of artistic casting: bel(le yệtere, bel(le $\sim$ māker, bel(le-man; 9) the names of masters of coining, forging and quarrying of silver and gold: gülder, gōld bēter, gōld smith, striker, washer(e. Viz. Table 1 of Appendix.

\subsubsection{Middle English native occupational terms with the only function of identification (58):}

1) the names of smelters and founders: *blọmere, *blọme smith, *bras $\sim$ yẹtere, *harder(e), *lēd yệtere; 2) the names of blacksmiths: *blăkk smith, *brǒun(e) stere, *brŏun smith, *grẹ̄ne ssmith, *lēd bētere, *lēd $\sim$ smith, *ōr $(e \sim$ smith, *shọ̄ $\sim$ smith, *smith-man; 3$)$ the names of turners and polishers: *grīndestere, *hōner, *whetter; 4) the names of craftsmen who make tools and craft instruments: *ax(e $\sim$ smith, ${ }^{*}$ cliter $\sim$ smith, * crōmbere, *hakker (e, *hamer maker, *shēre smith, *shă re makere; 5) the names of locksmiths: *keiere, *lokiestere, *lok-man, *lok wright; 6) the names of craftsmen who make household utensils: *canner, *panne bētere, 
*panne yẹ̄tere, *panner, *pot(e makere, *pot(e-man; 7) the names of craftsmen who make needles, wires, studs, spurs and nails: *bolt $\sim$ smith,


*biller(e, *blāder, *boltere, *bolt smith, *brănd wirchte, *gavelacer, *pǒunder maker, *shēthe-man, *shitel makere; 9) the names of masters of artistic casting: *beller; 10) the names of masters of coining, forging and quarrying of silver and gold: *fīler, *fîle heuer, *güldestere, *gōlder, *gōld finer, *gōld wir drauer, *gōld hōper, *silverer, *silver heuere. Viz. Table 2 of Appendix.

3.1.3. Middle English native occupational terms with the only function of classification (12):

1) the names of smelters and founders: yẹtere; 2) the names of blacksmiths: clothe-mēre, hamer bēter, hamer smiter; 3) the names of craftsmen who make tools and craft instruments: harwe maker; 4) the names of locksmiths: holere, keie makere; 5) the names of craftsmen who make household utensils: panne makere; 6) the names of masters of coining, forging and quarrying of silver and gold: gold smitheresse, silver makere, silver kepere, silver smith. Viz. Table 3 of Appendix.

Functional differentiation of native occupational terms within three groups gives the following results: a) 36 (34\%) wordsl fulfilled both the functions of classification and identification as common nouns and proper names; b) $58(55 \%)$ words fulfilled the only function of identification as proper names; c) 12 (11\%) words fulfilled the only function of classification as common nouns.

\subsection{Middle English loan-blends (70)}

Middle English names of workers in metal, which are the loan-blends, are 70 in number and constitute $33 \%$ of the total number of the Middle English names of workers in metal, and 7\% of the total number of the Middle English names of artisans. We distribute them within the following functional, etymological and semantic subgroups:

\subsubsection{Middle English loan-blends with both the functions of classification and identification (19)}

Viz. Table 4 of Appendix.

\section{Loan-blends with the Romance word-stems (12)}

\subsubsection{Loan-blends with the Latin word-stems (2):}

1) the names of craftsmen who make household utensils: coper-smith; 2) the names of craftsmen who make needles, wires, studs, spurs and nails: pinnere. 
3.2.1.2. Loan-blends with the Old French (Central French) wordstems (7):

1) the names of smelters and founders: $\operatorname{blauncher}(e$, latoner $(e ; 2)$ the names of craftsmen who make tools and craft instruments: card(e maker; 3 ) the names of armorers: bǒkeler makere, brōche maker; 4) the names of craftsmen who make needles, wires, studs, spurs and nails: brōche maker; $5)$ the names of masters of coining, forging and quarrying of silver and gold: monei (e $\sim \operatorname{ma} k e r(e$.

\subsubsection{Loan-blends with the Latin / Old French word-stems} (double origin) (3):

1) the names of craftsmen who make needles, wires, studs, spurs and nails: riveter, rivet(te drivere; 2$)$ the names of armorers: plät(e makere.

\section{Loan-blends with the Germanic word-stems (7)}

\subsubsection{Loan-blends with the Scandinavian word-stems (7):}

1) the names of blacksmiths: smithi-man;2) the names of craftsmen who make tools and craft instruments: harwere, plough wrighte; 3) the names of armorers: arwe smith, gǒnner, gonne maker; 4) the names of masters of coining, forging and quarrying of silver and gold: clipper.

3.2.2. Middle English loan-blends with the only function of identification (42)

Viz. Table 5 of Appendix.

\section{Loan-blends with the Romance word-stems (30)}

\subsubsection{Loan-blends with the Latin word-stems (5):}

1) the names of craftsmen who make household utensils: *ampuller, *coper beter, *copperer, *coper-man; 2) the names of craftsmen who make needles, wires, studs, spurs and nails: *pin maker.

\subsubsection{Loan-blends with the Old French word-stems (25):}

a) loan-blends with the Central French word-stems (14): 1) the names of turners and polishers: *roller; 2) the names of craftsmen who make tools and craft instruments: *balaunce maker; 3) the names of craftsmen who make needles, wires, studs, spurs and nails: *aglet makere, *barre maker, *bucklesmith, *brocher; 4) the names of locksmiths: *clok(ke maker; 5) the names of armorers: *brigandine maker, *chāpe maker, *gorğerer, *plate smith; 6) the names of masters of artistic casting: *chimbe maker; 7) the names of masters of coining, forging and quarrying of silver and gold: *garlander, *gōld fïner ( $<*$ finner $<$ fìnen [OF affiner]);

b) loan-blends with the Norman word-stems (4): 1) the names of 
craftsmen who make tools and craft instruments: *auncēl maker; 2) the names of craftsmen who make household utensils: *caudrǒun bọter, *vesseler; 3) the names of armorers: *brigander maker.

3.2.2.3. Loan-blends with the Latin / Old French word-stems (double origin) (7):

1) the names of craftsmen who make household utensils: *lantern(e maker, *pichẹ̆r(e makere; 2) the names of craftsmen who make tools and craft instruments: *anker smith, * rāsǒur(er, *rāsǒur(e smith; 3) the names of armorers: *plater, *plăt(e-man.

\section{Loan-blends with the Germanic word-stems (12)}

\subsubsection{Loan-blends with the Scandinavian word-stems (11):}

1) the names of smelters and founders: *is blouere, *iren brenner, *iren-man, *silver brennere; 2) the names of blacksmiths: *iren smith; 3) the names of craftsmen who make tools and craft instruments: *knif smith, *stithì (e makere; 4) the names of craftsmen who make needles, wires, studs, spurs and nails: *brod smith, *gadder; 5) the names of armorers: *arwe makere, *gǒnne maister.

\subsubsection{Loan-blends with the Low Germanic word-stems (1):}

- the names of smelters and founders: *bli $\sim$ gẹter.

\subsubsection{Middle English loan-blends with the only function of} classification (9)

Viz. Table 6 of Appendix.

Loan-blends with Romance word-stems (8)

3.2.3.1. Loan-blends with the Old French (Central French) wordstems (7):

1) the names of smelters and founders: metal yetere; 2) the names of blacksmiths: brake-man, metal maker, metal smith; 3) the names of masters of coining, forging and quarrying of silver and gold: coin clipper, coin $\sim$ smiter, coin washer.

3.2.3.2. Loan-blends with the Latin/Old French word-stems (double origin) (1):

- the names of craftsmen who make household utensils: scāler.

Loan-blends with the Germanic word-stems (1)

\subsubsection{Loan-blends with the Scandinavian word-stems:}

- the names of smelters and founders: îren heter. 
Table 1: Origin and usage of the Middle English names of workers in metal (loan-blends)

\begin{tabular}{|c|c|c|c|c|c|c|c|c|}
\hline \multirow{3}{*}{$\begin{array}{l}\text { Function/ } \\
\text { Origin of the } \\
\text { word-stem }\end{array}$} & \multicolumn{6}{|c|}{ Loan-blends (Hybridisms) } & \multirow{3}{*}{$\begin{array}{l}\text { Total } \\
\text { number }\end{array}$} & \multirow{3}{*}{$\begin{array}{l}\text { Ratio } \\
\text { (\%) }\end{array}$} \\
\hline & \multicolumn{4}{|c|}{ Romance } & \multicolumn{2}{|c|}{ Germanic } & & \\
\hline & $\mathrm{L}$ & $\mathrm{L} / \mathrm{F}$ & $\mathrm{CF}$ & $\mathrm{N}$ & Sc. & LG & & \\
\hline $\begin{array}{l}\text { Classification/ } \\
\text { Identification }\end{array}$ & 2 & 3 & 7 & - & 7 & - & 19 & 27 \\
\hline Identification & 5 & 7 & 14 & 4 & 11 & 1 & 42 & 60 \\
\hline Classification & - & 1 & 7 & - & 1 & - & 9 & 13 \\
\hline Total number & \multicolumn{4}{|l|}{50} & \multicolumn{2}{|l|}{20} & 70 & 100 \\
\hline Ratio (\%) & \multicolumn{4}{|c|}{71} & \multicolumn{2}{|l|}{29} & 100 & \\
\hline
\end{tabular}

The etymological distribution of the word-stems of 70 hybrid Middle English names of workers in metal is the following: a) 50 word-stems (71\%) are of Romance origin (Latin, Central French, Norman or double Latin/ Old French); b) 20 word-stems (29\%) are the Germanic words (Scandinavian or Low Germanic).

The analysis of their functional differentiation gives the following results: a) 19 names of workers in metal $(27 \%)$ fulfilled two kinds of the nominative function in the Middle English period, and were used as common nouns and proper names; b) 42 names of workers in metal $(60 \%)$ fulfilled the only function of identification as proper names; c) 9 names of workers in metal $(13 \%)$ fulfilled the only function of classification as common nouns.

\subsection{Lexical borrowings (33)}

Loan-words among the Middle English names of workers in metal are 33 in number, which constitutes $16 \%$ of their total number and $3 \%$ of the total number of the Middle English names of artisans. We distribute these loanblends within the following functional, etymological and semantic groups and subgroups.

\subsubsection{Borrowings with both the functions of classification and identification (9)}

Viz. Table 7 of Appendix.

Romance borrowings (9)

\subsubsection{Old French borrowings (7)}

a) Central French borrowings (5): 1) the names of blacksmiths: fêv(e)re, marshal; 2) the names of turners and polishers: fǒurbǒur; 3) the names of 
craftsmen who make needles, wires, studs, spurs and nails: lorimer; 4) the names of masters of coining, forging and quarrying of silver and gold: orfevre;

b) Norman borrowings (2): the names of turners and polishers: burnisher, cutelẹr.

\subsubsection{Borrowings of double (Latin / French) origin (2):}

1) the names of blacksmiths: ferrǒur; 2) the names of craftsmen who make household utensils: plumber (plumbiner).

\subsubsection{Borrowings with the only function of identification (5)}

Romance borrowings (5) Viz. Table 8 of Appendix.

\subsubsection{Latin borrowings (1):}

- the names of masters of coining, forging and quarrying of silver and gold: *arğentārie.

\subsubsection{Old French borrowings (4)}

a) Central French borrowings (3): a) the names of armorers: *quisser; 2) the names of craftsmen who make needles, wires, studs, spurs and nails: *aguler; 3 ) the names of masters of coining, forging and quarrying of silver and gold: *orbatǒur;

b) Norman borrowings (1): the names of craftsmen who make household utensils: *caudrŏner.

\subsection{Motivated borrowings}

3.4.1. Borrowings with both the functions of classification and identification (12)

\section{Romance borrowings (12)}

\subsubsection{Latin borrowings (1):}

- the names of masters of coining, forging and quarrying of silver and gold: minter.

\subsubsection{Old French borrowings (11):}

a) Central French borrowings (7): 1) the names of blacksmiths: fŏrğer; 2 ) the names of turners and polishers: furbisher; 3 ) the names of craftsmen who make needles, wires, studs, spurs and nails: bokelër; 4) the names of armorers: flecch $\overline{\bar{e}}$ (-iēr); 5) the names of masters of coining, forging and quarrying of silver and gold: coinour, finǒur, moneier;

b) Norman borrowings (2): 1) the names of armorers: armürěrr; 2) the names of craftsmen who make household utensils: peutrer.

\subsubsection{Borrowings of double (Latin / French) origin (2):}

1) the names of craftsmen who make household utensils: patener; 2) the 
names of armorers: hauberğer. Viz. Table 9 of Appendix.

\subsection{Motivated borrowings with the only the function of identification (4)}

There are 4 Middle English occupational terms, which can be considered as both the loan-words and the loan-blens, because they were borrowed together with their motivational bases; they fulfilled the only function of identification as proper names. We distribute them within the functional and etymological groups as follows:

\section{Romance borrowings (4)}

\subsubsection{Old French (Central French) borrowings (2):}

1) the names of armorers: *heaumer; 2) the names of craftsmen who make household utensils: *lanterner.

\subsubsection{Borrowings of double (Latin / French) origin (2):}

- the names of craftsmen who make household utensils: *cressetẹr, *potel(l)er. Viz. Table 10 of Appendix.

\subsection{Motivated borrowings with the only function of classification (3)}

There are 3 Middle English occupational terms, which are motivated borrowings with the only function of classification; they are distributed within the following functional and etymological groups:

\section{Romance borrowings (3)}

\subsubsection{Latin borrowings (1):}

- the names of masters of coining, forging and quarrying of silver and gold: ğemmāri.

\subsubsection{Old French (Central French) borrowings (2):}

1) the names of blacksmiths: förğeress $(e ; 2)$ the names of armorers: arteler. Viz. Table 11 of Appendix.

Table 2: Origin and functions of the Middle English names of workers in metal (lexical borrowings)

\begin{tabular}{|c|c|c|c|c|c|c|c|c|c|c|}
\hline \multirow{2}{*}{$\begin{array}{l}\text { Function/ } \\
\text { Origin }\end{array}$} & \multicolumn{4}{|c|}{ Loan-words } & \multicolumn{4}{|c|}{ Motivated loan-words } & \multirow{2}{*}{$\begin{array}{l}\text { Total } \\
\text { number }\end{array}$} & \multirow{2}{*}{$\begin{array}{l}\text { Ratio } \\
(\%)\end{array}$} \\
\hline & $\mathrm{L}$ & $\mathrm{L} / \mathrm{F}$ & $\mathrm{CF}$ & $\mathrm{N}$ & $\mathrm{L}$ & $\mathrm{L} / \mathrm{F}$ & $\mathrm{CF}$ & $\mathrm{N}$ & & \\
\hline $\begin{array}{l}\text { Classification/ } \\
\text { Identification }\end{array}$ & - & 2 & 5 & 2 & 1 & 2 & 7 & 2 & 21 & 64 \\
\hline Identification & 1 & - & 3 & 1 & - & 2 & 2 & - & 9 & 27 \\
\hline Classification & - & - & - & & 1 & - & 2 & - & 3 & 9 \\
\hline Total number & \multicolumn{4}{|c|}{14} & \multicolumn{4}{|c|}{19} & 33 & 100 \\
\hline Ratio (\%) & \multicolumn{4}{|c|}{42} & \multicolumn{4}{|c|}{58} & 100 & \\
\hline
\end{tabular}


Functional differentiation of 33 borrowed names of workers in metal gives the following results:

a) 21 names of workers in metal (64\%) fulfilled the functions of classification and identification, and were used in the Middle English period as common nouns and proper names;

b) 9 names of workers in metal $(27 \%)$ only fulfilled the function of identification as proper names;

c) 3 names of workers in metal (9\%) only fulfilled the function of classification as common nouns.

Etymological distribution of 33 borrowed Middle English names of workers in metal is the following:

a) $14(42 \%)$ words are the lexical borrowings of Romance origin (Latin, Central French, Norman or of double Latin/ Old French origin);

b) $19(58 \%)$ words are motivated loan-blends, i.e. we consider them either as lexical borrowings, or loan-blends formed on the basis of Romance vocabulary (Latin, Central French, Norman or of double Latin/ Old French origin).

\section{Conclusions and perspectives}

On the basis of personal names, we have obtained the data concerning etymological foundations, functioning and the first attestation of the Middle English vocabulary, as well as the spheres of influence of foreign languages, precise time of lexical borrowing and formation of hybridisms.

Table 3: The origin and functions of the Middle English names of workers in metal

\begin{tabular}{|l|l|l|l|l|l|l|}
\hline $\begin{array}{l}\text { Function/ } \\
\text { Origin }\end{array}$ & English & $\begin{array}{l}\text { Loan- } \\
\text { blends }\end{array}$ & $\begin{array}{l}\text { Loan- } \\
\text { words }\end{array}$ & $\begin{array}{l}\text { Motivated } \\
\text { loan-words }\end{array}$ & $\begin{array}{l}\text { Total } \\
\text { number }\end{array}$ & $\begin{array}{l}\text { Ratio } \\
\text { (\%) }\end{array}$ \\
\hline $\begin{array}{l}\text { Classification/ } \\
\text { Identification }\end{array}$ & 36 & 19 & 9 & 12 & 76 & 36 \\
\hline Identification & 58 & 42 & 5 & 4 & 109 & 52 \\
\hline Classification & 12 & 9 & - & 3 & 24 & 12 \\
\hline Total number & 106 & 70 & 14 & 19 & 209 & 100 \\
\hline Ratio (\%) & 51 & 33 & 7 & 9 & 100 & \\
\hline
\end{tabular}

Functional differentiation of Middle English names of workers in metal is the following:

1) $76(36 \%)$ words fulfilled the functions of classification and identification, and were used as common nouns and proper names;

2) $109(52 \%)$ words only fulfilled the function of identification as proper names;

3) $24(12 \%)$ words only fulfilled the function of classification as common nouns. 
Etymological distribution of 209 Middle English names of workers in metal is the following: 1) $106(51 \%)$ words are of native origin; 2) $70(33 \%)$ words are loan-blends; 3$) 33$ (16\%) words are loan-words.

These calculations led us to the following conclusions:

1) semantic group of the names of workers in metal was very numerous in the Middle English period - 209 words, constituting one of the predominant parts of the names of artisans $-21 \%$ and $9 \%$ of the total number of occupational terms;

2) the ratio of native words and the borrowings among the names of workers in metal (i.e. loan-blends and lexical borrowings added) is $1: 1$

3) the predominance of Romance vocabulary over the Germanic one among the word-stems of loan-blends is in ratio 5:2;

4) the origin of lexical borrowings is exclusively Romance;

5) the predominance of occupational terms with the function of identification over those with the function of classification is in ratio $9: 1$, proving the fact of extreme popularity of the names of workers in metal in the Middle English period.

Prospective studies of the evolution of Middle English semantic system, especially the issues of assimilation of lexical borrowings, and synonymy of native words and borrowings in the sets of synonyms, can be based on the results of our investigation.

\section{Sources}

DBS $=$ Reaney, Percy Hide. 1966. A dictionary of British surnames. London, Great Britain: Routledge and Kegan Paul.

MED = Lewis, Robert E. et al. (eds.). 1952-2001. Middle English dictionary. Ann Arbor: University of Michigan Press. (Online edition: McSparran, Frances et al. (eds.). 2000-2018. Middle English compendium. Ann Arbor: University of Michigan Library.)

OED $=$ Simpson, John \& Weiner, Edmund (eds.). 1989. The Oxford English dictionary, 2nd ed., 20 vols. Oxford, Great Britain: Oxford University Press.

\section{References}

Brylla, Eva. 2016. Bynames and nicknames. In Hough, Carole (ed.), The Oxford handbook of names and naming, 237-250. Oxford: Oxford University Press. DOI: 10.1093/oxfordhb/9780199656431.013.52

Dobrovolska, Oksana. 2016. Middle English names of merchants: Etymology and aspects of usage: SKASE Journal of Theoretical Linguistics 13(3), 46-68. 
(http://www.skase.sk/Volumes/JTL33/pdf_doc/04.pdf) (Accessed 201612-19.)

Dobrovolska, Oksana. 2017. Middle English names of professional entertainers: Etymology and aspects of usage: Studies about languages. (31), 5-22. DOI: http://dx.doi.org/10.5755/j01.sal.0.31.18644

Dobrovolska, Oksana. 2018. Reconstruction of Middle English lexical and semantic system evolution (a case study of occupational terms of the 11th15th centuries): An essay of doctoral thesis. Kyiv: Znannya. (https://dspace. uzhnu.edu.ua/jspui/handle/lib/21468) (Accessed 2021-03-19.)

Ekwall, Eilert. 1947. Early London personal names. Lund: C.W.K. Gleerup.

Fransson, Gustav. 1935. Middle English surnames of occupation (1100-1350). London; Lund: C.W.K. Gleerup, William \& Norgate.

Hanks, Patrick \& Coates, Richard \& McClure, Peter. 2016. The Oxford dictionary of family names in Britain and Ireland. Oxford: Oxford University Press.

Hanks, Patrick \& Parkin, Harry. 2016. Family names. In Hough, Carole (ed.), The Oxford handbook of names and naming, 214-236. Oxford: Oxford University Press. DOI: 10.1093/oxfordhb/9780199656431.013.9

McClure, Peter. 2010a. Middle English occupational bynames as lexical evidence: A study of names in the Nottingham borough court rolls 13031455. Part 1, Methodology. Transactions of the Philological Society 108(2), 164-177.

McClure, Peter. 2010b. Middle English occupational bynames as lexical evidence: A study of names in the Nottingham borough court rolls 13031455. Part 2, Etymologies. Transactions of the Philological Society 108(3), 213-231.

McClure, Peter. 2011a. Personal names and the development of English. OED Online. (http://public.oed.com/aspects-of-english/shapers-of-english/ personal-names-and-the-development-of-english/) (Accessed 2021-03-19.)

McClure, Peter. 2011b. Surnames as sources in the OED. OED Online. (http://public.oed.com/aspects-of-english/shapers-of-english/surnamesas-sources-in-the-oed/) (Accessed 2021-03-19.)

McClure, Peter. 2013. Explaining English surnames: Linguistic ambiguity and the importance of context. Part I. Nomina 36, 1-33.

McClure, Peter. 2014. Explaining English surnames: Linguistic ambiguity and the importance of context. Part II. Nomina 37, 109-141.

McClure, Peter \& Hanks, Patrick \& Coates, Richard. 2012. Methods for studying the origins and history of family names in Britain: philology meets statistics in a multicultural context. In Larsson, Lars-Gunnar \& Nyström, Staffan (eds.), Facts and findings on personal names: Some European examples. Proceedings of an International Symposium in Uppsala, October 20-21, 2011, 37-58. Uppsala: Acta Acadamiæ Regiæ Scientiarum Upsaliensis. 
Mills, A.D. 1968. Notes on some Middle English occupational terms. Studia Neophilologica: A Journal of Germanic and Romance Philology 40(I), 35-48.

Nyström, Staffan. 2016. Names and meaning. In Hough, Carole (ed.), The Oxford handbook of names and naming, 39-51. Oxford: Oxford University Press. DOI: 10.1093/oxfordhb/9780199656431.013.26

Otto, G. 1938. Die Handwerkerinamen in Mittelenglischen. N.p.: Bottrop.

Reaney, Percy Hide. 1967. The origin of English surnames. London: Routledge. Shilova, Natalia. 2006. Formirovanie sistemy proizvodnykh naimenovanii lits po professii $v$ angliiskom iazyke: Sfera remeslenno-promyshlennogo proizvodstva [The formation of a system of derivate occupational terms in modern English: The sphere of craft and industrial production]. Vladivostok. (Unpublished $\mathrm{PhD}$ thesis.)

Solonovich, Tatyana. 1986. Razvitie tematicheskoy gruppy naimenovaniy lits po professii $v$ angliyskom yazyke [The development of the thematic group of occupational names in the English language]. Minsk. (Unpublished $\mathrm{PhD}$ thesis.)

Tengvik, Gösta. 1938. Old English bynames. Uppsala: Almquist \& Wiksells Boktryckeri.

Thuresson, Bertil. 1950. Middle English occupational terms. Lund: C.W.K. Gleerup. 


\section{Appendix}

Table 1: Middle English native occupational terms as common nouns and personal names

\begin{tabular}{|c|c|}
\hline Common noun & Personal name \\
\hline 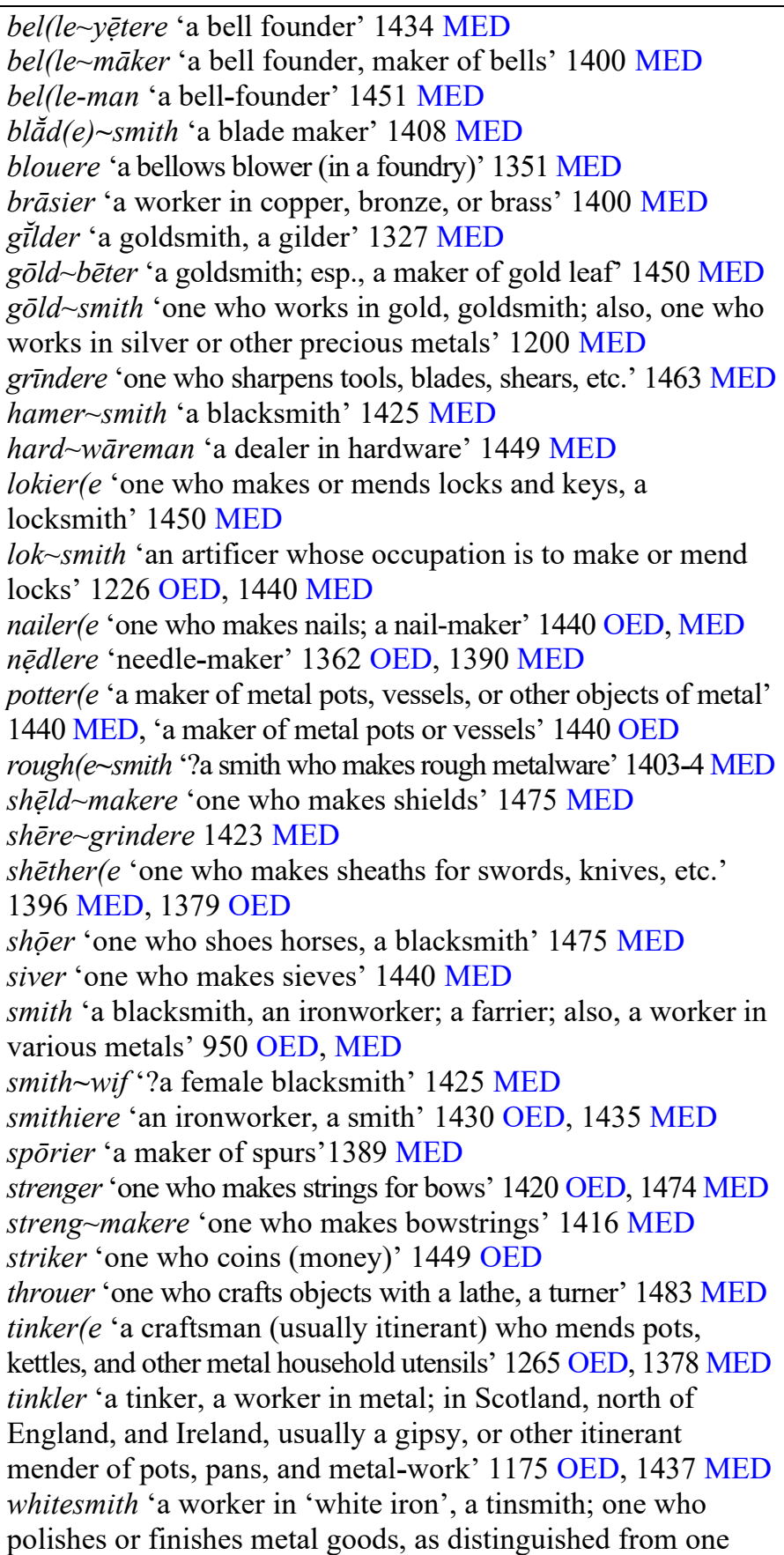 & $\begin{array}{l}\text { Belyotar } 1247 \\
\text { Belmaker } 1368 \\
\text { Belman } 1300 \\
\text { Bladsmith } 1357 \\
\text { Blowerre } 1199 \\
\text { Brasier } 1307 \\
\text { Gelder } 1281 \\
\text { Goldbeter } 1252 \\
\text { Goldsmyth } 1220 \\
\\
\text { Grindere } 1230 \\
\text { Hamersmyth } 1294 \\
\text { hardewareman } 1419 \\
\text { Lokier } 1221 \\
\\
\text { locksmith } 1226 \\
\text { Nailere } 1231 \\
\text { Nedler } 1221 \\
\text { potter } 1172 \\
\\
\text { Rowsmyth } 1408 \\
\text { Seldmakere } 1285 \\
\text { cheregrinder } 1347 \\
\text { Shethere } 1277 \\
\text { Schouger } 1309 \\
\text { Sevare } 1243 \\
\text { Smið } 975, \text { Smith } 1100 \\
\text { Smytheswyf } 1299 \\
\text { Smythiere } 1379 \\
\text { Sporier } 1281 \\
\text { Stringere } 1194 \\
\text { Strengmakere } 1338 \\
\text { Strykere } 1291 \\
\text { Thrower } 1282 \\
\text { Tynekere } 1265 \\
\text { Tinkelere } 1268 \\
\text { Wytesmith } 1260 \\
\end{array}$ \\
\hline
\end{tabular}




\begin{tabular}{|l|l|}
\hline who forges them; also, more widely, a worker in metals' 1302 & \\
OED; in surnames - MED & Wyrdraere 1264 \\
wir $\sim$ drawere 'a maker of wire' 1467 MED & Wassere 1293 \\
washer(e 'one who treats or washes coins with a corrosive \\
solution to remove some of the precious metal' 1450 MED
\end{tabular}

Table 2: Middle English native occupational terms as personal names only

\begin{tabular}{|c|c|}
\hline Reconstructed common noun & Personal name \\
\hline 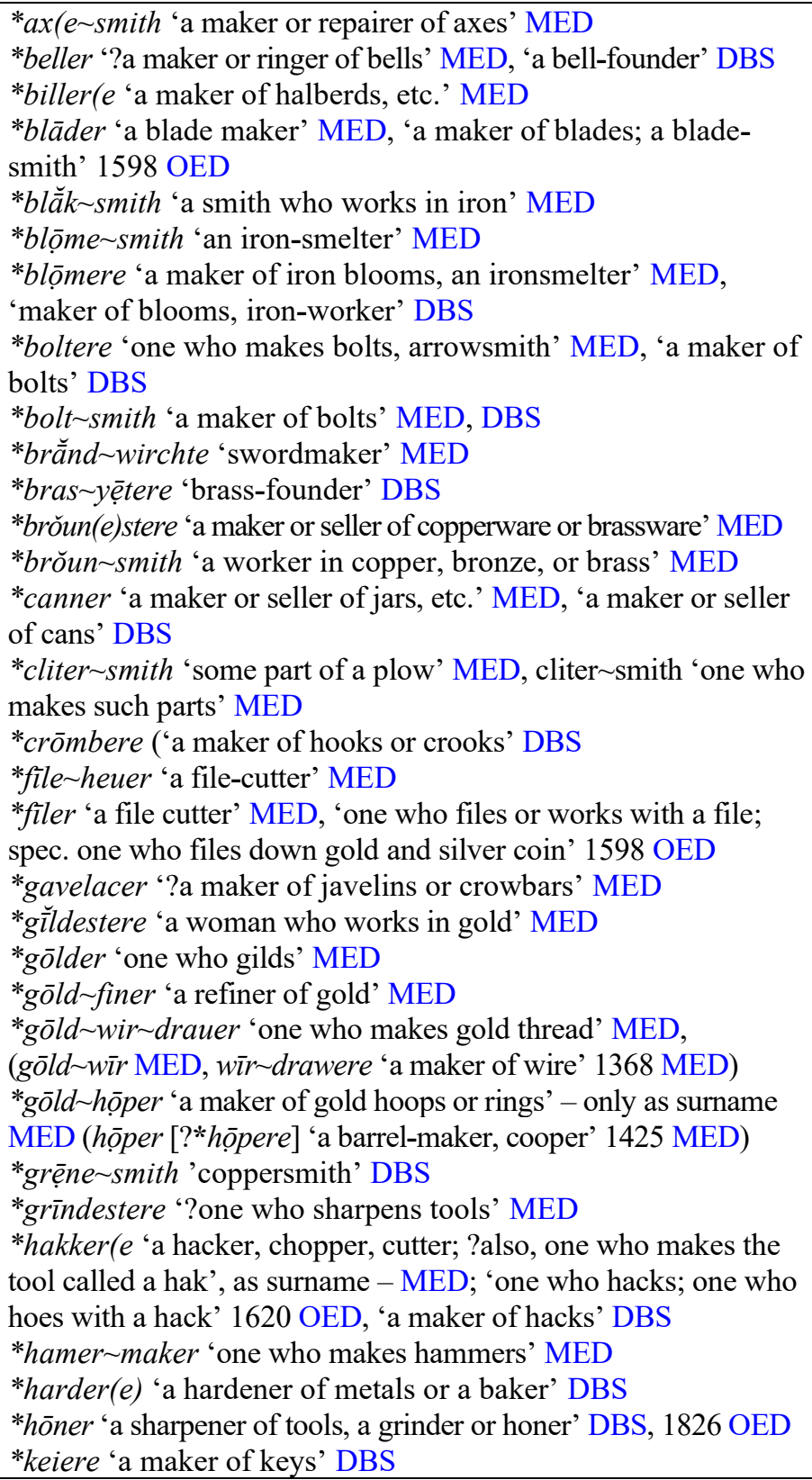 & $\begin{array}{l}\text { Exsmyth } 1299 \\
\text { Beller } 1281 \\
\text { Billere } 1275 \\
\text { Blader } 1305 \\
\text { Blakesmys } 1248 \\
\text { blomsmyth } 1408 \\
\text { Blomere } 1202 \\
\text { Boltere } 1180 \\
\text { Boltsmith } 1346 \\
\text { brandwirchte } 1103 \\
\text { Brasgetere } 1333 \\
\text { Brounestere } 1282 \\
\text { Brounesmyth } 1296 \\
\text { Kannere } 1305 \\
\text { Clitersmyth } 1309 \\
\text { Crombere } 1327 \\
\text { Filehewer } 1410 \\
\text { Filur } 1275 \\
\text { Gavelacer } 1327 \\
\text { Gildestere } 1303 \\
\text { Golder } 1290 \\
\text { goldfyner } 1437 \\
\text { Goldewirdrawer } 1463 \\
\text { Goldehoper } 1327 \\
\text { Grenesmyth } 1523 \\
\text { Grindestere } 1272 \\
\text { Hacker } 1224 \\
\text { Hambermakyer } 1357 \\
\text { Harder } 1220 \\
\text { honer } 1230 \\
\text { Cheigher } 1178 \\
\end{array}$ \\
\hline
\end{tabular}




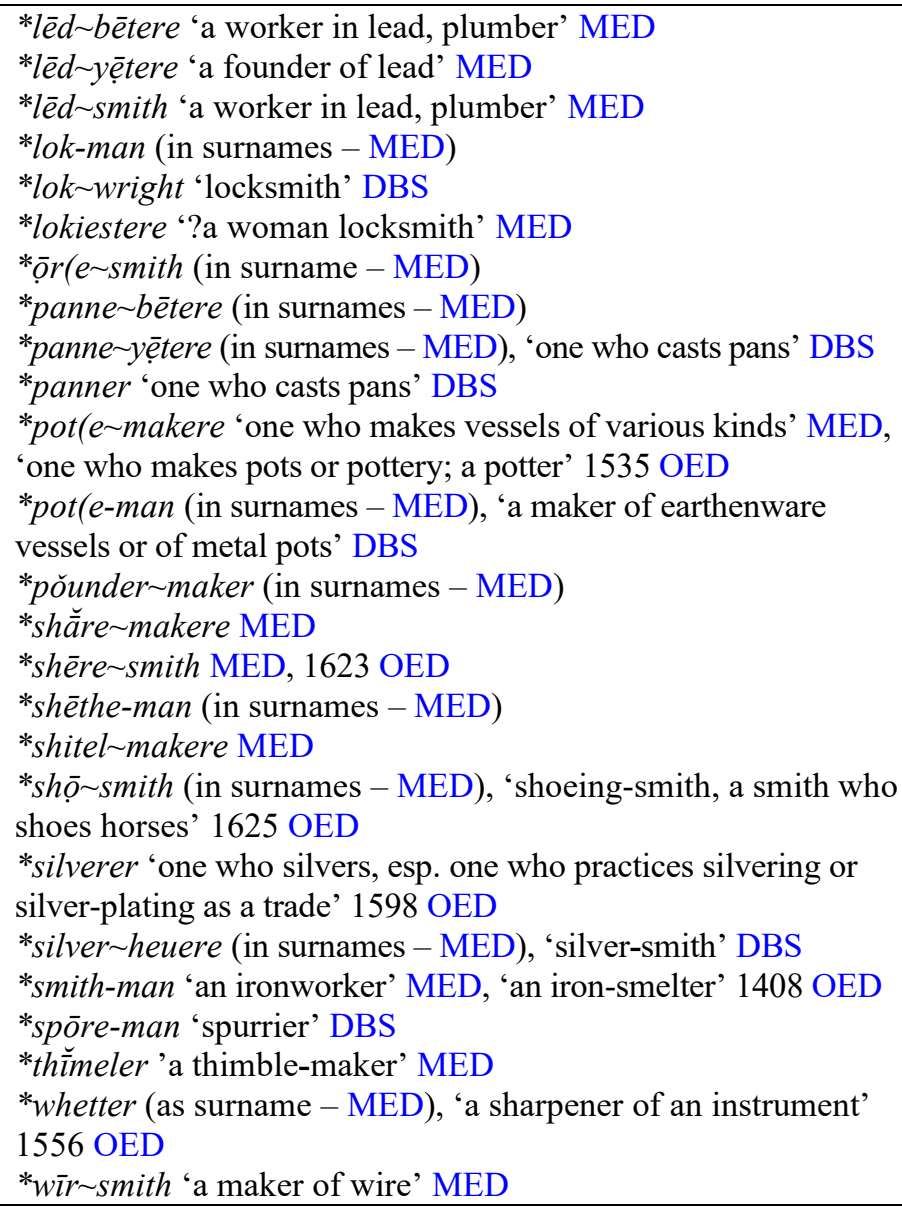

Ledbater 1221

Ledyetere 1280

Ledsmyth 1329

Loceman 1279

Locwricht 1300

Lokyestre 1288

Orsmyth 1292

panne betere 1210

Pannegetter 1250

Paner 1095

Potmaker 1297

Poteman 1185

Pundermaker 1286

Sharemakere 1343

Schersmyth 1264

Shatheman 1307

Schetilmaker 1361

Shosmith 1288

Sylvereour 1417

Silverhewer 1212

Smythman 1379

Spureman 1222

Thumeler 1332

Wetthere 1332

wiresmyth 1438

Table 3: Middle English native occupational terms as common nouns only

\begin{tabular}{|c|c|}
\hline Common noun & Meaning \& the first attestation \\
\hline $\begin{array}{l}\text { clōthe-mēre } \\
\text { gōld smitheresse } \\
\text { hamer bēter } \\
\text { hamer } \sim \text { smiter } \\
\text { harwe } \sim \text { maker } \\
\text { hōlere } \\
\text { keie } \sim \text { makere } \\
\text { panne } \sim \text { makere } \\
\text { silver kepere } \\
\text { silver makere } \\
\text { silver smith } \\
\text { yẹtere }\end{array}$ & $\begin{array}{l}\text { 'one who clothes mares, a blacksmith' } 1450 \text { MED } \\
\text { 'a female worker in gold' } 1450 \text { MED } \\
\text { 'a blacksmith' } 1382 \text { MED } \\
\text { 'a blacksmith' } 1382 \text { MED } \\
\text { 'a maker of harrows' } 1483 \text { MED } \\
\text { 'one who bores holes' } 1425 \text { MED } \\
\text { 'a keysmith'14 MED } \\
\text { 'a maker of pans' } 1475 \mathrm{MED} \\
\text { 'a silversmith' } 1483 \text { MED } \\
\text { 'a silversmith' } 1425 \text { MED } \\
\text { 'a silversmith' [OE seolfor-smip] 1382 MED } \\
\text { 'a smelter or founder of metal; also, one who casts metals' 1300 MED }\end{array}$ \\
\hline
\end{tabular}


Table 4: Middle English loan-blends as common nouns and personal names

\begin{tabular}{|c|c|c|}
\hline Origin & Common noun & Personal name \\
\hline Latin & 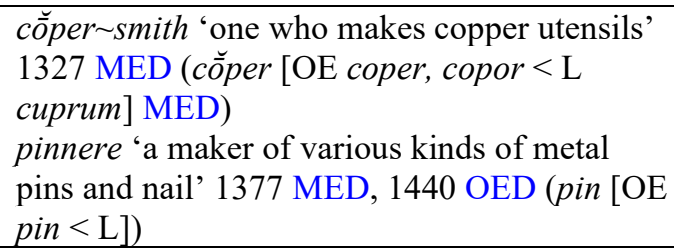 & $\begin{array}{l}\text { Copersmid } 1212 \\
\text { Pinare } 1244\end{array}$ \\
\hline $\begin{array}{l}\text { Central } \\
\text { French }\end{array}$ & $\begin{array}{l}\text { blauncher(e 'one who whitens metal' } 1400 \\
\text { MED (blaunchen [OF blancher]) MED } \\
\text { bǒkeler makere 'one who makes bucklers' } \\
1400 \mathrm{MED} \text { (bokeler, bǒkeler [OF bocler, } \\
\text { bucler]) MED } \\
\text { brōche maker } 1450 \mathrm{MED}, 1450 \text { OED (brōche } \\
\text { [OF]) } \\
\text { card(e maker 'a maker of wool cards' } 1399 \\
\text { MED, } 1401 \text { OED (card [F carde]) MED } \\
\text { latoner(e 'one who manufactures or works in } \\
\text { latten' 1392 MED, OED (latöun [OF laiton, } \\
\text { laton]) MED } \\
\text { monei(e māker(e 'a minter, moneyer' 1450 MED } \\
\text { (monei(e [OF moneie, monoie, monee]) MED }\end{array}$ & $\begin{array}{l}\text { Blauncher } 1273 \\
\text { Buklermaker } 1368 \\
\text { Bruche-maker } 1381 \\
\text { Cardemakere } 1346 \\
\text { Latoner } 1306 \\
\text { Monye maker } 1297\end{array}$ \\
\hline $\begin{array}{l}\text { Latin/ } \\
\text { Old French }\end{array}$ &  & $\begin{array}{l}\text { revtdryver } 1474 \\
\text { Revettour } 1307 \\
\text { Platemaker } 1297\end{array}$ \\
\hline Scandinavian & $\begin{array}{l}\text { arwe smith MED, 'a maker of iron arrow-heads' } \\
1400 \text { OED (arwe [OE ar(e)wan; cp. OI ör, } \\
\text { örvar]) MED } \\
\text { clipper 'one who clips coins' } 1338 \text { MED } \\
\text { (clippen [ON; cp. OI klippa]) MED } \\
\text { gǒnne maker 'one who makes cannon or } \\
\text { small firearms, a gunsmith' 1156 MED (gǒnne } \\
\text { [prob. ON; cp. OI gunnr]) MED } \\
\text { gǒnner 'maker of cannon or of small firearms, } \\
\text { a gunsmith' } 1437 \text { MED } \\
\text { harwere 'a maker of harrows' } 1475 \text { MED, } \\
1483 \text { OED (harwe [OE *hearwa < OE hyrwan } \\
\text { 'to abuse, ill-treat, etc.'; prob. OI herfi } \\
\text { 'harrow' \& harfr, Dan. Swed. harv, Norw. } \\
\text { dial. horv]) MED } \\
\text { plöugh wrighte 'a maker of plows, plowwright } \\
1440 \text { MED (plöugh [LOE plog, ploh (from } \\
\text { ON) \& ON; cp. OI plogr, Swed. plog, Dan. } \\
\text { plov. As an element in names, plough is most } \\
\text { freq. in area of the Danelaw] MED }\end{array}$ & $\begin{array}{l}\text { Aruesmyth } 1278 \\
\text { Cliper } 1300 \\
\text { Gunmaker } 1371 \\
\text { Gonner } 1345 \\
\text { Haruer } 1255\end{array}$ \\
\hline
\end{tabular}




\begin{tabular}{|l|l|l|}
\hline & $\begin{array}{l}\text { smithi-man 'a worker in a smithy' 1350 MED, 'an } \\
\text { iron-smith' 1400 OED (smithī [ON: cp. OI } \\
\text { smiðja]) MED }\end{array}$ & Smythyman 1308 \\
\hline
\end{tabular}

Table 5: Middle English loan-blends as personal names only

\begin{tabular}{|c|c|c|}
\hline Origin & Reconstructed common nouns & Personal name \\
\hline Latin & $\begin{array}{l}\text { *ampuller 'a maker of ampulles' MED } \\
\text { (ampulle [OE ampulla; L ampulla; OF } \\
\text { ampo(le), amp (o)ule]) } \\
\text { *coper beter (in surnames) MED } \\
\text { *copperer 'one who coppers, or works in } \\
\text { copper' } 1827 \text { OED (cöper [OE coper, copor < } \\
\text { L cuprum] MED) } \\
\text { *coper-man (in surnames) MED, 'maker of } \\
\text { copper utensils' DBS } \\
\text { *pin maker 'a metal worker engaged in } \\
\text { making various sorts of nails and pins' MED } \\
\text { (pin [OE pin < L]) }\end{array}$ & $\begin{array}{l}\text { Ampuller } 1309 \\
\text { Coperbeter } 1286 \\
\text { Copperer } 1327 \\
\text { Coperman } 1202 \\
\text { Pinmaker } 1350\end{array}$ \\
\hline $\begin{array}{l}\text { Central } \\
\text { French }\end{array}$ & $\begin{array}{l}\text { *aglet makere MED (aglet [OF aguillete]) } \\
\text { *balaunce maker MED (balaunce [OF } \\
\text { bala(u)nce) } \\
\text { *barre } \sim \text { maker (barre [OF]) } \\
\text { *brocher 'a maker of broaches (lances, spears, } \\
\text { etc.) or of broaches' DBS [ME broche, F } \\
\text { broche] } \\
\text { *brigandine maker MED (brigandine(s } \\
\text { [from OF]) } \\
\text { *buckle smith bokel smith MED, buckle- } \\
\text { smith } 1500 \text { OED (bokel, bǒkel [OF bocle, } \\
\text { bucle, boucle, bogle]) } \\
\text { *chāpe maker (chāpe [OF]) } \\
\text { *chīmbe maker MED (chimbe [OF chimbe]) } \\
\text { *clok(ke maker 'one who makes and repairs } \\
\text { clocks, a clock maker' MED (clok(ke [OF } \\
\text { cloke, cloque]) } \\
\text { *garlander 'a maker of garlands', metal } \\
\text { chaplets or circlets for the head adorned with } \\
\text { gold or silver' DBS (garland [OF garlande, } \\
\text { gerlande, gallande]) } \\
\text { *gorğerer 'an armorer who makes or sells } \\
\text { gorgets' MED (gorğĕer [OF gorgiere]) } \\
\text { *plate smith 'a maker of plate-armour or of } \\
\text { plates for armour' DBS (plate [ME plate, OF } \\
\text { plate]) } \\
\text { *roller (roll v. [OF roller, roler, etc., from roil, } \\
\text { rouil 'rust'] 'to polish, burnish' 1275 OED }\end{array}$ & $\begin{array}{l}\text { ageletmakere } 1365 \\
\text { Balaunsmaker } 1420 \\
\text { Barremakere } 1347 \\
\text { Brocher } 1222 \\
\text { Brygantyne maker } \\
\text { 1463 } \\
\text { Bokelsmyth } 1357 \\
\text { chapemaker } 1352 \\
\text { chyme maker } 1473 \\
\text { Clokkemakyer } 1374 \\
\text { Garlander } 1319 \\
\text { Goriurer } 1219 \\
\text { Platesmyth } 1379 \\
\text { Rollere } 1274\end{array}$ \\
\hline Norman & 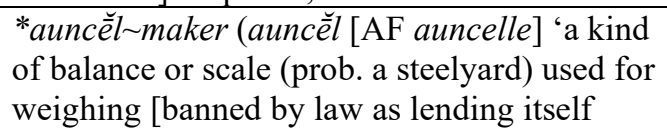 & ancermaker 1298 \\
\hline
\end{tabular}




\begin{tabular}{|c|c|c|}
\hline & $\begin{array}{l}\text { easily to deception' } 1303 \text { MED, auncē̌l maker } \\
\text { 'one who makes scales of this type' MED) } \\
\text { *brigander maker briganders maker MED } \\
\text { (briganders is formed on brigaund in ME or AF) } \\
\text { *caudrǒun bōter (caudrǒun [AF caud(e)roun } \\
\text { \& CF chaud(e)ron; cp. ML caldarium], bọter } \\
\text { 'one who mends or makes kettles') MED } \\
\text { *vesseler 'a maker or seller of household } \\
\text { vessels' DBS (vessel [AF, OF vessel: - L } \\
\text { vascellum; or AF and OF vessele, veselle, OF } \\
\text { vasselle, wasselle, vaissele, etc.: - L pl. } \\
\text { vascella and used in a collective sense] OED }\end{array}$ & $\begin{array}{l}\text { Bregander maker } \\
1468 \\
\text { Cauldrunboter } 1329 \\
\text { Wesseler } 1249\end{array}$ \\
\hline $\begin{array}{l}\text { Latin/ } \\
\text { Old French }\end{array}$ & 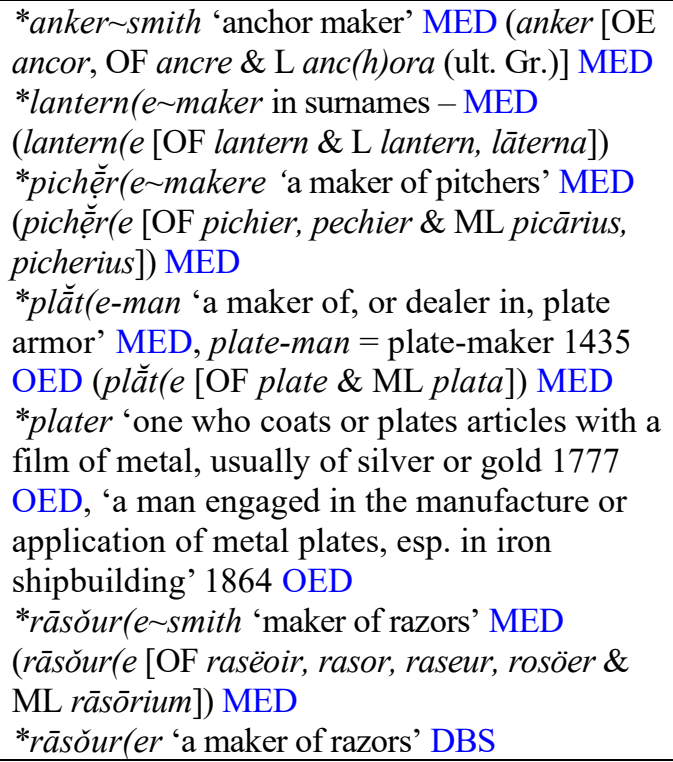 & $\begin{array}{l}\text { Ankersmit } 1300 \\
\text { Lanternemaker } 1374 \\
\text { Pichermakere } 1336 \\
\text { Playteman } 1435 \\
\text { Plaitere } 1279\end{array}$ \\
\hline Scandinavian & $\begin{array}{l}\text { *arwe } \text { makere MED ‘a maker of iron arrow- } \\
\text { heads' } 1400 \text { OED (arwe [OE ar(e)wan; cp. OI } \\
\text { ör, örvar]) MED } \\
\text { *brod smith 'a maker of goads, ?a maker of } \\
\text { nails' MED (brod [ON; cp. OI broddr]) MED } \\
\text { *gadder '?a maker of goads, '?one who casts metal } \\
\text { bars' MED (gad(de [ON; cp. OI gaddr]) MED } \\
\text { *gǒnne maister '?a master gusmith' MED } \\
\text { (gónne [prob. ON; cp. OI gunnr 'battle'], } \\
\text { maister [OF maistre, mestre, mastre \& OE } \\
\text { magister, maegester, from L]) MED } \\
\text { *is blouere (in surnames - MED, iren (is) ìren } \\
\text { [OE ìren \& isern, isen \& ON; cp. OI jārn, } \\
\text { ONorw. -jarn, OSwed. icern, Dan. jern], } \\
\text { blouere [OE blāwere]) MED } \\
\text { *īren brenner '?one who works at smelting } \\
\text { iron' MED (brennere 'one who makes bricks, } \\
\text { etc. by using fire' < brennen [ON, cp. OI } \\
\text { brenna]) MED } \\
\text { *iren-man (in surnames - MED) }\end{array}$ & $\begin{array}{l}\text { Aruwemakiere } 1305 \\
\text { bradsmyth } 1455 \\
\text { Gadder } 1285 \\
\text { Gunnemeyster } 1423\end{array}$ \\
\hline
\end{tabular}




\begin{tabular}{|c|c|c|}
\hline & 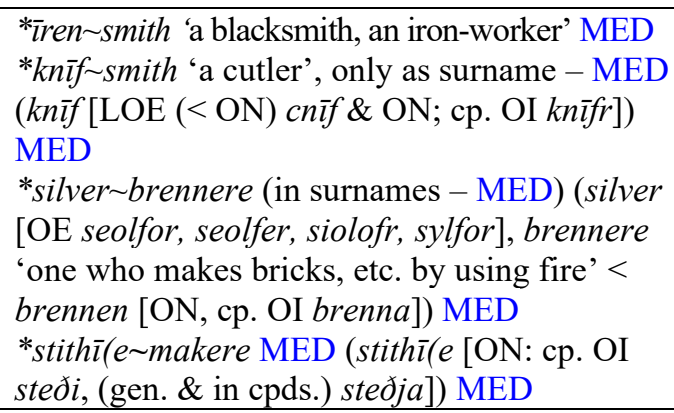 & $\begin{array}{l}\text { irensmyth } 1327 \\
\text { Knifsmith } 1246 \\
\text { Silverberner } 1279 \\
\text { stethymaker } 1413\end{array}$ \\
\hline Low Germanic & $\begin{array}{l}\text { *blī gẹter [MLG; cp. ON bly, MDu. blī \& ME } \\
\text { yẹtere] 'a lead founder' MED (yẹtere [from } \\
\text { yẹten v., OE gēotan] 'a smelter or founder of } \\
\text { metal; also, one who casts metals' } 1300 \text { MED) }\end{array}$ & Bligeter 1332 \\
\hline
\end{tabular}

Table 6: Middle English loan-blends as common nouns only

\begin{tabular}{|c|c|}
\hline Origin & Common noun \\
\hline $\begin{array}{l}\text { Central } \\
\text { French }\end{array}$ & $\begin{array}{l}\text { brāke-man 'a worker in metal; ?one who beats iron into bars' } 1435 \\
\text { MED (brāke [?cp OF bracon]) MED } \\
\text { coin clipper 'one who clips or shaves precious metal from coins' } 1422 \\
\text { MED (coin [OF coing, coin, cuign, quin }(g]) \text { MED } \\
\text { coin } \sim \text { smiter 'minter' } 1440 \text { MED } \\
\text { coin } \sim \text { washer 'one who 'sweats' metal from coins' } 1475 \text { MED } \\
\text { metal maker 'a metalworker' } 1382 \text { MED (metal [OF metal, metail] MED } \\
\text { metal } \sim \text { smith 'a metalworker' } 1382 \mathrm{MED} \\
\text { metal yetere 'a caster of metal, founder' } 1300 \mathrm{MED}\end{array}$ \\
\hline $\begin{array}{l}\text { Latin/ } \\
\text { Old French }\end{array}$ & $\begin{array}{l}\text { scāler '?a maker of weighing scales' } 1450 \text { MED (scāle [ML scāla; also } \\
\text { cp.OF escale (var. of eschale) \& ML scalia, scallia] MED) }\end{array}$ \\
\hline Scandinavian & $\begin{array}{l}\text { iren heter 'one who works the bellows or tends the furnace for } \\
\text { smelting iron' } 1425 \text { MED (îren (is) [OE ìren \& isern, ìsen \& ON; cp. } \\
\text { OI järn, ONorw. -jcern, OSwed. icern, Dan. jern] MED) }\end{array}$ \\
\hline
\end{tabular}

Table 7: Borrowings as Middle English common nouns and personal names

\begin{tabular}{|c|c|c|}
\hline Origin & Common noun & Personal name \\
\hline $\begin{array}{l}\text { Central } \\
\text { French }\end{array}$ & $\begin{array}{l}\text { ferrǒur (-ur) [OF ferreor] 'an ironworker, a } \\
\text { blacksmith; esp., a shoer of horses' } 1423 \\
\text { MED, ferrer [OF ferreor, ferour (F ferreur), } \\
\text { ML ferratōr-em] 'farrier' } 1426 \text { OED } \\
\text { fêv(e)re [OF] 'smith' } 1450 \text { MED } \\
\text { fóurbǒur [OF fourbeour, forb-] 'a smith who } \\
\text { polishes metal, a furbisher' } 1449 \text { MED, } \\
\text { furber [OF forbere, forbeor, agent-n. from } \\
\text { forbir 'to furbion'] = furbisher 1415 OED } \\
\text { lorimer [OF lormier, lorimier, lorennier] 'a } \\
\text { worker in small ironware; such as, bits, } \\
\text { harness, spurs, window bars, etc.' } 1200 \\
\text { MED, } 1225 \text { OED }\end{array}$ & $\begin{array}{l}\text { Fevre } 1233 \\
\text { Furbor } 1180\end{array}$ \\
\hline
\end{tabular}




\begin{tabular}{|l|l|l|}
\hline & $\begin{array}{l}\text { marshal (marescal) [OF mareschal, } \\
\text { marescal] 'a shoeing smith' 1130 OED } \\
\text { orfevre [OF] 'a goldsmith' 1450 MED; } \\
\text { orfever [F orfévre: - pop. L aurifabr-um } \\
\text { 'workman in gold, goldsmith'] 'a goldsmith' } \\
\text { 1415 OED }\end{array}$ & Marescal 1084 \\
\hline Norman & $\begin{array}{l}\text { Outelẹr [AF cuteler, CF coutelier] 'a } 1242 \\
\text { craftsman who makes cutting instruments, } \\
\text { such as knives, daggers, etc.; a cutler' 1396 } \\
\text { MED, cutler [F coutelier: - L type } \\
\text { cultellārius, from cultellus, OF coutel] 'one } \\
\text { who makes, deals in, or repairs knives and } \\
\text { similar cutting utensils' 1400 OED }\end{array}$ & Cuteler 1207 \\
\hline Latin/ French & $\begin{array}{l}\text { plumber [L plumbärius \& OF plomier] 'a } \\
\text { worker in lead, plumber; an installer or } \\
\text { repairer of lead roofs, gutters, pipes, etc' } \\
\text { 1408-9 MED, [OF plummier: - L } \\
\text { plumbarius] 'originally applied to a man who } \\
\text { dealt and worked in lead' 1385-6 OED }\end{array}$ & Plumberre 1102-7 \\
\hline
\end{tabular}

Table 8: Borrowings as Middle English personal names only

\begin{tabular}{|l|l|l|}
\hline Origin & Reconstructed common noun & Personal name \\
\hline Latin & *arǧentārie [L] 'a silversmith' MED & argentarie 1384 \\
\hline $\begin{array}{l}\text { Central } \\
\text { French }\end{array}$ & $\begin{array}{l}\text { *aguler [OF aguillier] 'one who makes or } \\
\text { sells needles; - only in names MED; cf. } \\
\text { aquiler [OF aguille 'needle'] 'a needle-case' } \\
\text { 1400 OED) } \\
\text { *orbatǒur (ore- [OF orbatëor] 'goldsmith' } \\
\text { MED } \\
\text { *quisser [OF cuissiere, cuissir] 'a maker of } \\
\text { thigh armor' MED }\end{array}$ & Laguillier 1188 \\
\hline Norman & $\begin{array}{l}\text { *burnisher [AF bornissour, CF brunissëor] } 1279 \\
\text { 'one who polishes armor' MED } \\
\text { *caudrŏner (cauldron, caldron [ME } \\
\text { caud(e)ron, -oun, AF and ONF caud(e)ron, } \\
\text {-oun: - L caldārium] }\end{array}$ & Bornissour 1309 \\
\hline
\end{tabular}

Table 9: Motivated borrowings as Middle English common nouns and personal names

\begin{tabular}{|l|l|l|}
\hline Origin & Common noun & Personal name \\
\hline Latin & $\begin{array}{l}\text { minter [OE mynetere < L] 'one who stamps } \\
\text { or coins money, a moneyer' 950 OED, 1126 } \\
\text { MED (mint }(e \text { [OE mynet < L] MED) }\end{array}$ & Myntere 1221 \\
\hline $\begin{array}{l}\text { Central } \\
\text { French }\end{array}$ & $\begin{array}{l}\text { bokelër [OF bo }(\text { u }) \text { clier] 'a maker of buckles' } \\
1435 \text { MED }(\text { bokel, bókel } \text { n. [OF bocle, } \\
\text { bucle, boucle, bogle] MED) } \\
\text { coinŏur 'one who makes coins, minter' 1440 } 1148\end{array}$ & boner 1202 \\
\hline
\end{tabular}




\begin{tabular}{|c|c|c|}
\hline & $\begin{array}{l}\text { MED, OED (coin v. [OF coignier, cungner], } \\
\text { cunye n. [15th c. Sc. cunze, repr. OF cuigne, } \\
\text { var. of coin] 'coin, money' } 1375 \text { OED, } \\
\text { coin n. [F coin] 'a die, stamp, piece of } \\
\text { money' } 1362 \text { OED) } \\
\text { finǒur [CF fineur] 'a refiner of metal' } 1400 \\
\text { MED (finen v. [OF affiner] MED) } \\
\text { flecchēer (-iēr) (-ǒur) [OF flecher, -ier] 'a } \\
\text { maker or seller of arrows' } 1330 \mathrm{MED} \\
\text { fŏrğer (-êr, -eóur) [OF forgiere, -eur] 'one } \\
\text { who works at a forge, a smith' } 1382 \mathrm{MED} \\
\text { furbisher (-ŏur) [OF fourbisseur] 'one who } \\
\text { polishes, a furbisher' } 1400 \mathrm{MED,} \mathrm{OED} \\
\text { (furbishen [from OF stem fo(u)rbiss- of } \\
\text { fo(u)ubir] MED) } \\
\text { moneier 'a minter' [OF monoiier, } \\
\text { monneiere, monnier] } 1425 \mathrm{MED} \mathrm{(monei(e} \\
\text { [OF moneie, monoie, monee] MED) }\end{array}$ & $\begin{array}{l}\text { Finor } 1189 \\
\text { Flecher } 1203 \\
\text { Forgeore } 1315 \\
\text { Furbisur } 1260 \\
\text { Moneer } 1207\end{array}$ \\
\hline Norman & $\begin{array}{l}\text { armürĕ̌r [AF armurer, OF armurier, -eurier] } \\
\text { 'one who makes or repairs armor or weapons, } \\
\text { an armorer' } 1385 \mathrm{MED}, 1400 \mathrm{OED} \\
\text { peutrer [AF; cp. CF peautrier] 'one who } \\
\text { manufactures or works in pewter' } 1348 \mathrm{MED}\end{array}$ & $\begin{array}{l}\text { Armurer } 1268 \\
\text { Peauterer } 1311\end{array}$ \\
\hline Latin/French & $\begin{array}{l}\text { hauberğer [OF haubergier \& ML } \\
\text { haubergerius] 'a maker of coats of mail; } \\
\text { only as surname' MED, } 1481 \text { OED (hauberk } \\
[\mathrm{OF}, \mathrm{ML}] \mathrm{MED}) \\
\text { patener [L patenārius] 'a patten-maker' } \\
\text { 1466-7 OED (paten (patyn) [OF patène from } \\
\text { L patena, patina] OED, patēn(e [OF patene } \\
\& \text { ML patena] MED) }\end{array}$ & $\begin{array}{l}\text { Haubergier } 1201 \\
\text { Patener } 1290\end{array}$ \\
\hline
\end{tabular}

Table 10: Motivated borrowings as Middle English personal names

\begin{tabular}{|l|l|l|}
\hline Origin & Reconstructed common noun & Personal name \\
\hline $\begin{array}{l}\text { Central } \\
\text { French }\end{array}$ & $\begin{array}{l}\text { *heaumer [OF heaumier] 'a helmet maker' } \\
\text { MED (heaume [F heaume - OF. helme] 'a } \\
\text { massive helmet, reaching down to the } \\
\text { shoulders, worn in the 12th and 13th } \\
\text { centuries, s/t over a smaller close-fitting one' } \\
\text { 1572 OED; OFr heaumier, heumier 'maker } \\
\text { of helmets' DBS; cf. helm [OE helm, OF } \\
\text { helme (mod. F. heaume)] 725 OED) } \\
\text { *lanterner (as surname only - MED) [from } \\
\text { lantern(e \& OF lanternier] 'lanter-maker, a } \\
\text { supplier of lanterns' MED (lantern(e [OF } \\
\text { lanterne \& L lanterna, lāterna] MED) }\end{array}$ & Launterner 1298 \\
\hline Latin/ French & $\begin{array}{l}\text { *cressetẹr [from cresset; cp. ML cressetarius] } \\
\text { 'a maker or seller of cressets' MED (cresset } \\
\text { [OF craisset, crasset] MED) }\end{array}$ & Cressetter 1316 \\
\hline
\end{tabular}




\begin{tabular}{|l|l|l|}
\hline & $\begin{array}{l}\text { *potel(l)er [from potel(le; also cp. ML } \\
\text { potellāre] 'a maker or seller of pottles' MED } \\
\text { (potel(le [OF potel \& ML potellus] MED) }\end{array}$ & Poteler 1265 \\
\hline
\end{tabular}

Table 11: Motivated borrowings as Middle English common nouns

\begin{tabular}{|c|c|}
\hline Origin & Common noun \\
\hline Latin & ǧemmārie [L] 'a jeweler’ 1382 MED \\
\hline $\begin{array}{l}\text { Central } \\
\text { French }\end{array}$ & $\begin{array}{l}\text { arteler [OF artiller] 'a maker of arms' } 1437 \text { MED } \\
\text { förğeress(e }[\mathrm{OF}] \text { 'a female worker in metal (used fig.), creator' } 1430 \\
\text { MED }\end{array}$ \\
\hline
\end{tabular}

